\title{
Subjectification Processes in the Religious Tradition (Problem Statement)
}

\author{
Iuriy F. Abramov, \\ Vladimir I. Kuybar' and Alexei E. Smirnov* \\ Irkutsk State University \\ 1, Karl Marx Str., Irkutsk, 664003, Russia
}

Received 08.11.2014, received in revised form 04.11.2014, accepted 17.01.2015

The objective of the article is to outline the possible field of the religion research related to the processes of subjectification in religious traditions. Various religious traditions form up different type of cultures in psychic activity, or different subject profiles. It appears important to answer the questions on how and by what means such formation becomes possible. What happens to the person having religious experience? What is the "mechanism" of the religious experience' influencing the subject habitude of an individual? It is known that in such situation those are not only interests, values, horizons, circle of contacts, but also the perception of reality, habits, types of reactions, attractions and affects that change. What are the subjective transformations of an individual recognizing the relevance of religion? How can this process be described from the structural, nonpsychological point of view? In this work we briefly outline the history of the problem, the level of its development, the methodological principles and methods of for research.

Keywords: subject, subjectification, religious traditions, religious experience, religious practice, social-heterological method, Orthodox tradition.

Research area: philosophy.

If building the ontology of religiosity is one of the primary tasks of religion studies, then one of its most relevant strands is the problem of creating the theoretical model of the experiencer, the subject of religious experience. The first scholar researching the influence of religious experience on the subject and the peculiarities of its existence was W. James. He described the phenomenon of religious experience and its constitutive consequences for the subject from the psychological point of view, relying on the philosophical pragmatism positions. Those were the works by James that started the first wave of religious experience studies within the framework of psychology of religion that lasted till the late 30 -s. Along with that, phenomenology, and later the hermeneutics of religion were being formed. The ambiguousness and specificity of the object of studies were revealed back on that stage. Atheistic scholars regarded religious experience and its influence on subjective habitude as a result of "brainwash"; the researchers representing the neutral position referred to the impossibility to objectify "the happening" of religious

(C) Siberian Federal University. All rights reserved

* Corresponding author E-mail address: aesmir@mail.ru 
experience, therefore, underlining its unique character. Due to the dramatic growth of new religious movements in the $70-\mathrm{s}$, the interest to the religious experience problem was resumed. That was when the sociology of religion came up. And again, a lot of lively discussions were caused by both the nature and the character of religious experience, just like by the definition of such. What are the transformations of subjective structures that can be related to the influence of religious experience? What changes in the subject having the experience, and how do the changes happen? What are the criteria for the authenticity of the religious tradition experience? The definition of religious experience as such still remains a source for many arguments. Works by modern researchers systematize the theoretic postulates used today for conceptualization of religious experience and religious conversion and provide a wide range of references. The definition of religious experience is studied within a wide sociocultural paradigm; a great amount of research approaches to the phenomenon are analyzed.

However, the questions on how religious practice influences the organization of subjectiveness, and on the "mechanism" of religious conversion still remain open to a great extent. How can one explain the reason why a person, for no apparent cause, suddenly turns to faith, and the fact that, having come to believe, he becomes a different person?

Religious experience is suffered, tolerated, borne, assimilated by the experiencer. Consequently, the first aspect of the problem of the religious experience's influence on the subjective habitude of an individual is formulated as follows: what is the process of subjectification, the process of forming the subject? What are the logical and methodological conditions and analytical means for recognition of the subject formation process?
Each religion institutionalizes its religious experience. It provides the authentic comprehension of this experience by the subject within the religious tradition framework as an organized and regular process in different forms of cult and theoretic activity. The second aspect of the problem is the necessity for formalization of religious experience as the content of religious tradition [1]. In other words, to define the influence of religious experience on the subjective habitude of the individual, it should be defined from the point of view of the structural conditions of the opportunity for its happening, not by the content of such.

The third aspect of the problem is associated with the creation of methodological program for researching the influence of religious experience on the subjectiveness formation. By what means is the subject of religious tradition established and reproduced? What are the specific religious practices that set the subject's certain means for obtaining subjectivity, implying conscious and(or) unconscious work on the organization, normalization, canalization of the affects, passions, desires, establishment of personal and collective identity, social status, social role etc.?

As the present research puts up the question on the structural conditions of the possibility of religious experience as such, it correlates with such branches of religion studies as phenomenology of religion (which studies the invariant structures of religion). Due to the necessity of statement of the issue on the means for cognition of the subjectivity transformed under the influence of religious experience', the project aids the development of religious hermeneutics (the tasks of which include the art of comprehending the homo religiosus). Due to the fact that the present research deals with a social subject transformed under the influence of various religious practices, and the fact that both the subject and the religious practices are considered as functions or happenings of social 
structures, institutions, social relations (not as a primary event), the present project is relevant from the point of view of developing sociology of religion (intended to explain both the social tendencies of religion itself, and the social genealogy of its elements and structure).

As for scientific novelty of the research, it may be classified into theoretical-methodology and substantial. The theoretical-methodological novelty is the development of such social subject concept, which would provide the basis to present it in the modus of formation instead of establishment. The substantial novelty of the research implies development of the theory of subjectification in religious tradition intended to explain not the "what", but the "how" of religion: how the subjective structures of an individual are transformed under the influence of a religious tradition practice [2].

Analysis of the modern condition of research on the problem of the influence of a religious tradition experience on the subjective habitude of an individual is divided into two parts. The first part of the research concerns the problem of the religious tradition substance and the religious experience definition, considered not by its substance, but from the point of view of its existence and functioning. The second part of the research is connected to the problem of the subject of religious experience, as here the subject also needs to be thought of in the process of formation, transformation and metamorphosis.

The problem of substance of religious tradition implies answering the questions, what and by what means is conveyed by religious tradition. Among Russian researchers, the problem was studied by V.S. Sementsov, V.V. Maliavin, S.S. Averintsev [3], A.V. Kuraev [4]. The problem of means of translation of religious experience was covertly explored by S.S. Khoruzhiy in his spiritual practice concept [5]. For the analysis of the problem of religious experience expression, works by P.A. Florenskiy on the spatial and temporal characteristics of spiritual experience in works of art remain relevant [6]. He was also the one to develop the problem of body as a specific means and result of religious experience. Within the framework of analytic anthropology, the topological characteristics of spiritual experience were studied in works by V.A. Podoroga [7] and V.M. Toporov [8] (based on philosophy and literature).

As for the strands of religion studies within which the stated problem is found, the first of them are hermeneutics and phenomenology of religion. It is worth noticing that the mentioned areas of expertise should be regarded as trends or tendencies, as phenomenology of religion, just like hermeneutics of religion, still lack internal integrity today. The rare modern projects of neophenomenologyofreligion(post-phenomenologies of religion) are developed on the basis of these or those versions of philosophic hermeneutics. Thus, phenomenology of religion by P. Ricœur is based on the fundamental ontological hermeneutics by M. Heidegger, and phenomenology of religion by $\mathrm{W}$. Gantke is based on dialogic hermeneutics by O. Bol'nov. Nevertheless, works by J. Wach, F. Heiler, M. Eliade, W. Gantke, C.J. Bleeker, J. Waardenburg, W. King and other representatives of classic and modern phenomenology have a significant methodological potential leading to certain conclusions on the influence of the experience of religious tradition on the subjective habitude of an individual.

The second part of the researches dedicated to the problem of forming subjectiveness implies a greater number of theoretical scenarios, as the fate of the experiencer is one of the themes playing a significant role in determining the fate of modern philosophy. The corpus of social and philosophic approaches related to the problem of subjectiveness, subjectivity and subjectification started to systematically appear from the middle 
of the $19^{\text {th }}$ century together with the emergence of themes and practices of neoclassic philosophy. The main figures in it are F. Nietzsche and S. Kierkegaard. Subjectiveness is not any more regarded as a hindrance according to the measures of cognitive standards. One hundred years after, subjectiveness was interpreted as the main power and form of developing sociality (V.E. Kemerov), or as a post-industrial economy resource (A. Gorz, T. Sakaiya, D. Bell, T. Stewart, A. Toffler). An important step in comprehension of subjectivity was made by the post-dialectic concepts of establishment (H. Bergson, E. Husserl, W. James, A. Whitehead, M. Foucault, G. Deleuze), and the "experimental" forms of philosophic thinking and artistic practice (W. Benjamin, G. Bataille, M. Heidegger, T. Adorno, V. Khlebnikov, M. Proust, J. Derrida). The problem of production and formation of subjectiveness is turning into an interdisciplinary field of study; a number of works tangentially related to the formation of subjectiveness is getting enormous. Among the schools and disciplines that dealt with the problematizing the classic definition of subject, we may outline post-structuralism and philosophic discourses of post-modernist kind (J.-F. Lyotard, R. Barthes, G. Deleuze, J. Lacan, J. Derrida, J.-L. Nancy, P. Lacoue-Labarthe). The theme of revolutionary subjectiveness and its political and epistemological significance was developed by post-Marxists (C. Castoriadis, S. Žižek, E. Laclau, Ch. Mouffe, A. Badiou, A. Negri, M. Hart).

A significant contribution into the development of the problem of body and subjectivity was made by the representatives of feminist philosophy (L. Irigaray, J. Butler, Dorothy E. Smith). Starting from the late $20^{\text {th }}$ century, there are found some attempts of building the subject formation processes' analysis. The most outstanding of them are: interpellation theory by L. Althusser (and adjacent works by S. Žižek) and the concept of "subject to truth" by
A. Badiou. The central position in this series is occupied by M. Foucault; the theme of historicity of subjectification processes became the rid line in his works starting from the late $70-$ s. The problem of its formation and the problem of its expression is a traditional theme for the sector of analytic anthropology of the Philosophy Institute of Russian Academy of Science under the leadership of Professor V.A. Podoroga. Distinctive methodological capacity is typical of works by Professor T.Kh. Kerimov, who developed "social heterology", a special discipline within the framework of social philosophy, providing conceptual means for working with open, decentralized experiencer and incomplete, "nonsufficient" sociality [9]. Thus, the most relevant branches that problematize the classic subject figure, are post-structuralism, philosophic postmodernism, post-Marxism, deconstructive feminism. Among the main tendencies within which this problem is developed, we may name, first of all, philosophy of difference, that refuses regarding being as the basis; secondly, social heterology (as application of the principles of philosophy of difference to socio-philosophical problems), and thirdly, the philosophical terms and practices questioning the integrity, selfidentity, homogeneousness and autonomy of the social subject [10].

The main methodological principles of the research are the ideas of 1) historicity of subjectiveness and 2) precedurality (technicality) of subjectiveness and 3) casualty of subjectiveness.

Subjectiveness is historical, which means that in each historical age, in each culture there existed multiple attitudes to the self, implying certain practices of treating the self. Attitude of a person towards themselves and the practices of self-treatment establish the specific methods of obtaining subjectiveness that imply conscious or unconscious work on regulation, normalization, 
canalization of affects, passions, desires, determination of personal and collective identity, social status, social role etc. The social subject remains "static", which means retaining a certain type of the subject profile as long as the practices are intact and able to reproduce its subjective configuration.

Subjectiveness is procedural (technical). Subjectiveness is exposed to transformative influences, which means that subjectiveness is procedural and always technically mediated. The moment of "technicality" is formally and substantially necessary for constructing any form of subjectiveness. There is no "primary" subjectiveness or "subjectiveness as such". There is no "internal" subjective that exists without the forming, reproducing and supporting "external" component. The emergence of subjectiveness is preceded by certain procedures, techniques or practices. The thesis on the procedurality of subjectiveness opens the possibility to study the relation between the subject and the other, nonsocial and non-human, or to think of technicality and subjectiveness without mutual restriction. There is no "between" between technicality and subjectiveness: technicality and subjectiveness imply no opposition [10].

Subjectiveness is occasional, which means that between subjectivity and the relevant practices (and/or procedures) there are no clearly determined relations. For the forming subjectivity "being" means coming into life, and it does not necessarily means actualization. Despite the relations of determination, subordination and even mutual subordination subjectiveness is brought to being by multiple mobile spatial-temporal instances in the continuous process of mutual "co-ordination" (P.A. Florenskiy). According to this logic, everything brought to existence is continuously "co-ordinated" in relation to each other in such a way, that every purpose or being is essentially temporary, operational and at the same time completely determined by the open sum of compatibility of things in existence.

The methodological base of the research is a complex of approaches related to works by M. Heidegger, J. Derrida, G. Deleuze, M. Foucault. Methodological significance of works by M. Heidegger is twofold; first, these are methodological implication of Daseinanalysis, and secondly, they represent the ontological difference and conception of being as happening. The conceptual apparatus of fundamental ontology enables us to present the forming subjectivity as openness (to being), excluding being approached as self-identity and presence for itself. Heidegger's discovery of the ontological difference allows regarding the process of subject formation (subjectification) as objective uncertainty, along with pointing at the type of relation between the anthropological subjectiveness and subjectivity as such [11].

The contribution of J. Derrida is associated with the idea of deconstruction and indication of the constitutive role of the "insolvabilities". Thus, deconstruction of the concept of subject allows revealing the theoretical and methodological conditionality of the problem, and the thesis on the fundamental role of "insolvability" states the idea of regarding subjectification as a principally endless process.

For building the theoretical model of subjectification processes in religious tradition, the idea of differential attitude, the terms of "actual" and "virtual", and the idea of being as difference can be adopted from G. Deleuze. Finally, the thesis of the historicity of subjectiveness and the possibility of causing various transformative influences on the subjective habitude of an individual are adopted from M. Foucault.

The idea on the virtual nature of subjectification processes is not ungrounded, indeed. The primary postulate explaining the possibility of such suggestion is the immutability of 
the emergence and existence of such phenomenon in the act and time of the individual's interaction with various practices [12]. This is where the procedurality, technical intermediariness, casualty and co-ordination reveal themselves. Further the authors of the current research plan to develop the idea and apply the informationalvirtual approach to it [13], the more so as the virtual nature of spirituality as the derivate of religious and other traditions, experience and practices has already been proven [14].

An important methodological resource is the approach allowing working with open, nonsufficient or "radical" sociality. It is practiced and developed by V.E. Kemerov, T.Kh. Kerimov, S.A. Azarenko. We should also notice the outstanding works by J.-L. Nancy dedicated to the actualization of the theoretical resources of Heidegger's Mitsein. In this prospective, subjectification is regarded as the event of sharing the mutuality with the other.

The diversity of the approaches listed above is coordinated with the help of socialheterological approach, the productivity of which is proven by the fact that it introduces the new frame in which such evident elements as "consciousness", "soul", "substance", "I" do not occupy the dominating position. The significance of the social-heterological method is the possibility of thinking of the existence of the individual in the social, "the other" within the structure of "I". Social-heterological principle asserts plurality which is always greater than integrity. Any social existence means inclination from integrity to plurality, and a subject being in the process of formation in religion is always something more than just its self-expression in the "introspection" and the symbolism of the cult practice, learning the doctrinal statement, theology etc. [15].

It appears that theoretical-methodological realization of the influence made by religious experience on the subject habitude of an individual opens a new field for research in religion studies, associated with the processes of subjectification (subject formation) in religious traditions. The analysis of the subjectiveness structuring mechanisms in various religious traditions means an opportunity to understand the peculiarity of the spiritual experience underlying different civilization types. For instance, revealing the subjectification technologies of the Orthodox tradition may be regarded as a component for a wider genealogical analysis describing the latent maturing of Russian World as a global sociocultural being. The timeliness of this aspect is explained by the necessity for Russia's selfidentification in the modern globalization process, for maintenance of cultural and religious identity of Russia, for escape from the accrued models and stereotypes, for the recreation of spiritual and moral basics of the society.

Theoretical results of the research may form the base for development of separate postulates of a scientifically-based policy for collective subjects of various levels, of development conceptions for social institutions and religious organizations. The proceedings of the research may be also used for complex development of subjectification technologies in conformity with various professional needs, and for the development of theoretical and methodological basics for the global and regional missionary work of Russian Orthodox Church.

\section{References}

1. Smirnov A.E. O soderzhanii religioznoy traditsii i sredstvakh transliatsii religioznogo opyta [On the Content of Religious Traditions and Means of Religious Experience Translation] // Irkutsk State University Newsletter. Series: Political science. Religion studies. No.9, p.248-255, 2014.

$$
-547-
$$


2. Smirnov A.E. Religioznoe obraschenie i problema ontologii sub'ekta [Religious Expression and Subject Ontology Problem] // Irkutsk State University Newsletter. Series: Political science. Religion studies. No.9, p. 231-242, 2014.

3. Al'manakh Vostok-Zapad. Issledovaniia. Perevody. Publikatsii. [East-West Almanac. Research. Translations. Publications]. Moscow: Nauka, 1988.

4. Kuraev A. Traditsiia. Tserkov'. Chelovek [Tradition. Church. Person] // Put'. International philosophy magazine. No.2, p. 183-201, 1992.

5. Khoruzhiy S.S. Fonar' Diogena. Kriticheskaia retrospektiva evropeyskoy antropologii [Diogenes' Torch. Critical Retrospect of European Anthropology]. Moscow: St. Thomas Institute of Philosophy, Theology and History, 2010.

6. Florenskiy P.A. Analiz prostranstvennosti i vremennosti v khudozestvenno-izobrazitel'nykh proizvedeniiakh [Spatiality and Temporality Analysis in Artistic and Expressive Art Works]. Moscow: Progress, 1993.

7. Podoroga V.A. Vyrazhenie i smysl [Expression and Sense]. Moscow: Ad Marginem, 1995.

8. Toporov V.N. Sviatost' $i$ sviatye v russkoy dukhovnoy kul'ture [Holiness and the Saints in Russian Spiritual Culture]. Volume 1. Moscow: Gnozis, 1995.

9. Kerimov T.Kh. Bytie i razlichie. Genealogiia i geterologiia [Being and Difference. Genealogy and Heterology]. Moscow: Akademicheskiy proekt, 2011.

10. Smirnov A.E. Protsessy sub'ektivatsii: teoretiko-metodologicheskie aspekty [Subjectification Processes: Theoretical and Methodological Aspects]. Irkutsk: Scientific Centre of Reconstructive and Rehabilitation Surgery of the Siberian Branch of Russian Academy of Medical Science, p. 232-248, 2011.

11. Smirnov A.E.Protsessysub'ektivatsii: sotsial'no-filosofskiy analiz [Subjectification Processes: Social and Philosophical Analysis]. Author's abstract from the Dissertation for the Degree of Doctor of Philosophy, Buryat State University. Ulan-Ude, 2012. P.24-26.

12. Kuybar' V.I. K voprosu o virtual'nykh formakh sotsial'nykh vzaimodeystviy vinformatsionnom obschestve [To the Question of Virtual Forms of Social Interactions in the Information Society] // Krasnoyarsk State University Newsletter. Humanitarian Sciences. No.6, p.22-27. Krasnoyarsk, 2006.

13. Abramov Iu.F., Kuybar' V.I. Kategoriia “informatsionno-virtual'naia real'nost”” kak faktor razvitiia nauchno-filosofskogo znaniia (teoretiko-metodologicheskiy aspekt) ["Information and Virtual Reality" Category as a Factor for Developing the Scientific and Philosophic Knowledge (Theoretical and Methodological Aspect)] // Buryat State University Newsletter. Philosophy. Sociology. Political Science. Culture Studies. No.6, p. 44-50. Ulan-Ude, 2010.

14. Abramov Iu.F., Kosolopov R.A., Kuybar' V.I. Kontsept $i$ struktura fenomena dukhovnosti v sovremennom religiovedenii [Concept and Structure of Spirituality Phenomenon in Modern Religion Studies] // Irkutsk State University Newsletter. Political Science. Religion Studies. No.1, p. 241-250. 2015.

15. Kerimov T.Kh. Sotsial'naia geterologiia [Social Heterology]. Yekaterinburg: UralNAUKA, 1999. 


\title{
Процессы субъективации в религиозной традиции (К постановке проблемы)
}

\author{
Ю.Ф. Абрамов, \\ В.И. Куйбарь, А.Е. Смирнов \\ Иркутский государственный университет \\ Россия, 664003, Иркутск, ул. Карла Маркса, 1
}

\begin{abstract}
Цель статьи - очертить возможное поле религиоведческих исследований, связанных с процессами субъективации в религиозных традициях. Различные религиозные традиции формируют различные типы культуры психической деятельности, или различные субъектные профили. Нам представляется важным ответить на вопросы о том, каким образом и за счет каких средств осуществляется такое формирование. Что происходит с человеком, переживающим религиозный опыт? Каков “механизм” влияния религиозного опыта на субъектную конституцию индивида? Известно, что в данной ситуации меняются не только интересы, иенности, кругозор, круг общения, но также и восприятие действительности, привычки, типь реакиий, влечений, аффектов. Каковы субъектные трансформации индивида, осознающего для себя значимость религиозного? И как со структурной, не психологической точки зрения описать этот прочесс? В данной статье мы кратко освещяаем историю проблемы, степень ее разработанности, а также методологические принципы и методы ее исследования.
\end{abstract}

Ключевые слова: субъект, субъективачия, религиозные традиции, религиозный опыт, религиозная практика, социально-гетерологический метод, православная традиция.

Научная специальность: 09.00.00 - философские науки. 